УДК 346.1

В. Слатвінська,

магістр права факультету міжнародно-правових відносин Національного університету «Одеська юридична академія»

\title{
ЩОДО ВИЗНАЧЕННЯ ПОНЯТТЯ МЕХАНІЗМУ ГОСПОДАРСЬКО-ПРАВОВОГО РЕГУЛЮВАННЯ ВОДНОГО ТРАНСПОРТУ В ТРАНСПОРТНІЙ СИСТЕМІ УКРАЇНИ
}

Проблематика як механізму правового регулювання загалом, так і механізму господарсько-правового регулювання зокрема не є новою в юридичній науці. Проте нагальна необхідність грунтовного аналізу та докладного вивчення господарською наукою механізму господарсько-правового регулювання водного транспорту зумовлена декількома факторами. Якщо, з одного боку, можна сказати, що потреба у виявленні механізму господарсько-правового регулювання морського та річкового транспорту спричинена відсутністю досліджень, те саме неможливо сказати про інший діаметральний аспект: концепт «механізм господарсько-правового регулювання водного транспорту» корелює 3 такими поняттями, як «механізм господарсько-правового «господарсько-правовий «механізм правового регулювання», «господарсько-правове регулювання» та «правове регулювання», а це, треба визнати, суттєво збагачує уявлення про наявні наукові розробки. Так, наприклад, дослідженню окремих аспектів господарсько-правового механізму присвячені праці таких українських учених, як А. Бобкова, А. Демидова, Р. Кузьмін, В. Полюхович та ін. Механізм правового регулювання досліджували Н.Г. Александров, С.С. Алексєєв, В.М. Горшенєв, В.П. Казимирчук, Ф.М. Фаткуллін, Ф.Ф. Фаткуллін, Р.О. Халфіна, В.Ф. Яковлєв. Серед сучасних вітчизняних науковців, публікації яких пов'язані 3 дослідженням правового регулювання, можна назвати таких як Т.Г. Андрусяк, С.С. Алексєєв, С.В. Бобровник, А.М. Вітченко, В.В. Головченко, В.М. Горшенєв, I.Я. Дюрягін, О.В. Зайчук, А.П. Заєць, В.Б. Ісаков, Т.В. Кашаніна, М.І. Козюбра, A.M. Колодій, В.В. Копєйчиков, В.П. Корельський, Є.Б. Кубко, В.В. Лазарєв, С.Л. Лисенков, О.М. Мельник, Н.М. Оніщенко, М.П. Орзіх, М.Ф. Орзіх, В.П. Пастухов, В.І. Попов, А.С. Піголкін, П.М. Рабінович, С.П. Рабінович, Ю.С. Решетов, В.К. Самігулін, В.М. Селіванов, В.Ф. Сіренко, О.Ф. Скакун, В.О. Сумін, О.Д. Тихомиров, В.В. Цвєтков, Ю.С. Шемшученко, А.Ф. Черданцев, Л.С. Явіч. Однак відсутність у теорії господарського права спеціальних наукових розробок щодо механізму господарсько-правового регулювання водного транспорту зумовлює актуальність грунтовних наукових досліджень у цьому напрямі як з теоретичного, так і практичного поглядів.

Метою статті є розроблення поняття механізму господарсько-правового регулювання водного транспорту, виявлення складників i визначення його місця в наявних $\mathrm{y}$ юридичній науці механізмах і транспортній системі України.

Передусім спробуємо зрозуміти, що асоціюється 3 категорією «механізм господарсько-правового регулювання водного транспорту». Примітно, що це поняття є похідним від концептів «механізм» (найширший) і «механізм господарсько-правового регулювання» (вужчий).

Було б несправедливо не згадати той факт, що поняття «механізм» 


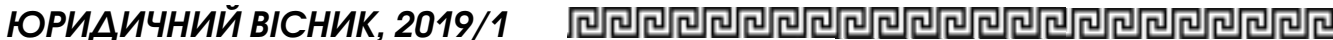

широко відоме в багатьох суспільних науках. Для правової науки України більш характерними є дослідження категорії «механізм правового регулювання» та його окремих елементів [1, с. 28], а для науки господарського права й економічних наук - категорії «господарський механізм» [2]. У спеціальних наукових дослідженнях останніх років досить широкого застосування набув термін «господарсько-правовий механізм».

Розглядаючи співвідношення понять «господарський механізм» і «механізм господарсько-правового регулювання», можемо констатувати, що господарський механізм займає «серединне» становище в механізмі використання економічних законів, будучи його найважливішим приводом. Що стосується місця правового фактору в розглянутих поняттях, то, на нашу думку, господарський механізм насамперед включається в господарське право як певна система правових норм. Сюди не можуть увійти господарські правовідносини, оскільки це вже початкова стадія реалізації правових норм. Механізм господарсько-правового регулювання входить у ширше поняття - механізм використання економічних законів [3, c. 32-33].

Проте через певну специфіку сфери водного транспорту, відповідно, і його механізм має особливі й притаманні лише йому риси. У зв'язку з цим надаємо авторське визначення поняття «механізм господарсько-правового регулювання водного транспорту» як системи правових засобів, спрямованих на впорядкування господарських відносин на водному транспорті, що реалізується за допомогою суб'єктів організаційно-господарських повноважень і господарсько-правового регулювання водного транспорту.

Тепер спробуємо віднайти місце цього механізму серед інших в обігу господарського права.

Варто зазначити, що оскільки право $€$ цілісною системою, то, відповідно, йому притаманний єдиний механізм правового регулювання. Поділ права на галузі, а їх, у свою чергу, на інститути не означає, що кожен із них має власний механізм. Відповідно, говорячи про механізм господарсько-правового регулювання водного транспорту, доцільно мати на увазі, що він є складником загального механізму правового регулювання, а не окремим самостійним механізмом. У зв'язку з цим механізму господарсько-правового регулювання водного транспорту притаманні риси загального механізму правового регулювання.

Серед характерних ознак правового механізму можна виділи такі:

1) об'єктивний характер - це особливі конструкції позитивного права (його структурна частина). Конкретний правовий механізм - нормативне відбиття об'єктивних матеріальних і духовних умов життя конкретного соціуму, панівної парадигми юридичного мислення, його правового менталітету й культури;

2) суб'єктивний аспект: а) будь-які правові конструкції - плід діяльності правотворчих суб'єктів як носіїв індивідуальної та групової свідомості й досвіду; б) механізм є таким тільки в разі його включення (теоретичного або практичного) у структуру відповідної практики, а також його постановки в певне співвідношення з метою цієї практики. Ніяка правова норма або інститут самі по собі не мають властивості бути засобом або механізмом досягнення мети. Така характеристика з'являється в них лише тоді, коли суб'єкт сприймає ї інструментально або використовує ї як інструменти;

3) телеологічний (цільовий) аспект. Закономірною властивістю правового механізму, що пояснює його функціональне призначення, є те, що він сконструйований для практичного використання, в остаточному підсумку, для досягнення конкретної мети або декількох цілей. Під певну мету» підбирається необхідний «набір» правового інструментарію;

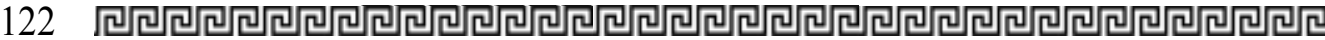


4) системний характер. Правовий механізм - органічна система, стійкий комплекс взаємозалежних правових інструментів, призначених «працювати» як єдине ціле. Практично вагомою характеристикою правового механізму є завершеність інструментальної структури;

5) правові механізми - це особливі конструкції позитивного права, що формалізують певний «набір» юридичних регуляторів (правових засобів), таких як права, обов'язки, заборони, принципи, презумпції, фікції, строки, процедури, заходи заохочення, відповідальності тощо. Правовий механізм $€$ комплексним юридичним засобом [1, c. 35].

Механізм господарсько-правового регулювання складається з таких компонентів: принципи, методи, господарські правовідносини, акти реалізації господарсько-правових норм, господарсько-правова відповідальність [4, с. 26]. Водночас механізм господарсько-правового регулювання водного транспорту має певні особливості, які зумовлені низкою обставин. Специфікою правового регулювання морського та річкового транспорту є тісна взаємодія приватноправових і публічно-правових засобів, оскільки в транспортній сфері взаємодіють як приватні, так і публічні інтереси. Насамперед це зумовлено важливістю транспортної системи для будь-якого індивідуума та економіки будь-якої держави загалом. Транспортна система України включає декілька видів транспорту, кожен із яких має свою специфіку, що не виключає можливостей виділення загальних рис. Ще одним специфічним фактором $€$ тривала історія правового регулювання транспортних відносин. Дуже небагато інших цивільно-правових інститутів мають «вік» у кілька століть. Особливо наочно це демонструється на прикладі морського транспорту.

Так, елементами механізму господарсько-правового регулювання водного транспорту $є$ норми права, юридичні факти, правовідносини, вико- нання обов'язків, акти захисту порушених прав і законних інтересів. Водночас механізм має певну специфіку, яка полягає в широкому застосуванні міжнародних нормативно-правових актів, типових договорів, стандартних форм чартерів (проформ), істотній ролі звичаїв та узвичаєнь, підзаконних нормативно-правових актів.

Тепер перейдемо до проблемних аспектів тлумачення концепту «транспортна система».

Серед транспортників тривають дискусії щодо використання понять «транспортна система» та «єдина транспортна система». На законодавчому рівні ця проблема також наявна. Яскравим прикладом є II розділ Закону України «Про транспорт», який оперує поняттям «транспортна система», а в статті 21 того ж розділу використовує поняття «єдина транспортна система» без його легального тлумачення, але 3 уточненням складу компонентів [5].

Наводимо доктринальні визначення поняття «транспортна система» - взаємопов'язана організаційна структура підприємств та організацій, які спеціально займаються перевезенням вантажів і пасажирів (транспорт загального користування), а також самостійних підприємств і структурних ланок підприємств і виробничих об'єднань промисловості, будівництва та інших галузей народного господарства (відомчий транспорт)» $[6$, с. 10], «сукупність усіх видів транспорту, що утворюють єдину транспортну систему, яка покликана здійснювати узгоджену (скоординовану) транспортну діяльність і керівництво нею, складається 3 наділених господарською компетенцією й таких, що перебувають у стійких господарських зв'язках, ланок, які діють як господарські системи, що очолюються транспортними міністерствами, або як господарські органи, що очолюються іншими органами господарського керівництва» [6, с. 14], сукупність засобів перевезення, шляхів сполучення, засобів управління та зв'язку, технічні споруди, що забезпечують їх роботу 


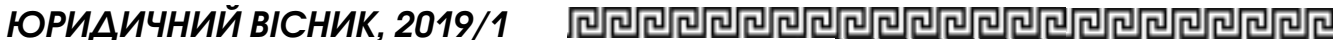

[7, с. 148], транспортна інфраструктура, усі види транспортних засобів, система управління й працівники транспортної сфери в сукупності, що забезпечують узгоджений взаєморозвиток і функціонування перерахованих вище iі елементів з метою максимального задоволення транспортних потреб населення і промисловості [8, с. 58], одна з галузей національної економіки, що має складну інфраструктуру, складники якої взаємопов'язані між собою та водночас існують відносно відокремлено одна від одної, взаємодіють між собою в рамках визначеної мети [9, c. 12].

Натомість $є$ й інше поняття «єдина транспортна система» - сукупність ефективно взаємодіючих незалежно від форми власності й відомчої підпорядкованості видів транспорту - шляхів сполучення і транспортних засобів, засобів для навантажувально-розвантажувальних робіт, що забезпечують перевезення людей і вантажів із використанням сучасних прогресивних технологій з метою найкращого задоволення попиту населення й вантажовласників на транспортні послуги $[10$, с. 6], сукупність різних видів громадського транспорту, об'єднаних єдиним державним плануванням, однорідними функціями із забезпечення потреб економіки в перевезеннях, єдиним уніфікованим правовим регулюванням» $[11$, с. 15-16], єдиний, оснований на використанні певного виду транспорту господарський комплекс, створений для планомірного ведення транспортно-господарської діяльності й керівництва нею, що складається 3 наділених господарською компетенцією й таких, що перебувають у стійких зв'язках, ланках, одна $з$ яких $є$ центром системи, має майно та здатна діяти на основі госпрозрахунку [12, с. 237], сукупність внутрішньо узгоджених, взаємопов'язаних, соціально однорідних транспортних засобів, 3 допомогою яких забезпечується організуючий і стабілізуючий вплив на виконання основних завдань у перевезеннях, що відображає їх структуру [13, с. 53].

На нашу думку, обидва поняття варто використовувати в науковому обігу транспортного права, але за однієї істотної умови - з розумінням їх змістового наповнення.

По-перше, вони не $є$ тотожними. По-друге, вони співвідносяться як частина й ціле.

Пропонуємо зупинитися детальніше на наведених нами наукових гіпотезах.

Якщо детально проглянути II розділ Закону України «Про транспорт», бачимо, що єдина транспортна система є лише одним зі складників транспортної системи. Тому поняття «транспортна система» широке, адже включає в себе, крім єдиної транспортної системи, ще взаємодію підприємств різних видів транспорту й координацію діяльності всіх видів транспорту.

Хоча визначенню поняття «транспортна система» вченими-правознавцями приділено увагу, проте з їхньою думкою щодо поданих вище визначень транспортної системи погодитися не можна з таких підстав. По-перше, в основному вищевказані визначення є неповними, по-друге, більшість визначень сформовані на підставі вивчення радянського законодавства і є дещо застарілими.

На нашу думку, транспортна система - комплекс єдиної транспортної системи, взаємодіючих підприємств різних видів транспорту й суб́'єктів, що здійснюють координацію діяльності всіх видів транспорту, який функціонує задля задоволення транспортних потреб населення, промисловості та економіки.

Пропонуємо розглянути місце механізму господарсько-правового регулювання водного транспорту в транспортній системі. Нагадаємо, що ці два компоненти є системами за своєю сутністю, проте перший компонент має правовий характер, а другий - техніко-логістичний. Якщо транспортна система є внутрішнім елементом, то механізм господарсько-правового регулювання водного транспорту є зовнішнім. Тобто вони співвідносяться як 
зміст і форма; вплив і залежність між ними $є$ взаємними. Крім того, обидві системи є динамічними і стрімко змінюють форму. У транспортній системі це виражається, наприклад, через інноваційність технологічних рішень, зокрема йдеться про наукові ноу-хау днопоглиблюваних робіт у портах, або конструювання спеціальної техніки (оновлення інфраструктури), або зміну класів портів, також зміну ролі видів транспорту разом із потребами споживачів транспортних і портових послуг. Як бачимо, транспортна система дуже чутлива до змін у суспільстві, науковому прогресі, економіці. Натомість механізм господарсько-правового регулювання водного транспорту в транспортній системі як правовий інструмент, безперечно, перебуває в постійному розвитку. Він указує на певний вектор можливого рішення правовою думкою загальної проблеми, створює правове поле для вже наявних транспортних правовідносин. Тож механізм регулює ipso facto й не завжди встигає за стрімким розвитком нагальних потреб.

Підбиваючи підсумки, можна сказати, що практична спрямованість виявлених категорій «механізм господарсько-правового регулювання водного транспорту» i «транспортна система» зумовлена такими факторами: по-перше, доктрина транспортного права неповною мірою відповідає сучасним викликам наявного рівня транспортних відносин, по-друге, факт дискусійності категорії «транспортна система» підштовхує до винайдення єдиного підходу до розуміння. Зрештою, у науковий доробок транспортного права внесена ясність у категоріальний апарат, що має на меті його зважене вживання.

Ключові слова: механізм правового регулювання, транспортна система, господарсько-правове регулювання, транспорт, водний транспорт.

Стаття присвячена науковому розробленню авторського поняття «механізм господарсько-правового регулювання водного транспорту» система правових засобів, спрямованих на впорядкування господарських відносин на водному транспорті, яка реалізується за допомогою суб'єктів організаційно-господарських повноважень $i$ господарсько-правового регулювання водного транспорту. Приділена увага категоріям «транспортна система» та «єдина транспортна система» з їх обгрунтованим розмежуванням. Виявлені ознаки $i$ складники механізму, а також визначене місие механізму серед наявних у науковому обігу механізмів $і$ в транспортній системі України.

Статья посвящена разработке авторского понятия «механизм хозяйственно-правового регулирования водного транспорта» - система правовых средств, направленных на упорядочение хозяйственных отношений на водном транспорте, которая реализуется с помощью субъектов организаизионно-хозяйственных полномочий и хозяйственно-правового регулирования водного транспорта. Уделено внимание категориям «транспортная система» и «единая транспортная система» $c$ их обоснованным разграничением. Обнаружены признаки и составляющие механизма, а также определено место механизма среди имеющихся в научном обороте механизмов и в транспортной системе Украины.

The article is devoted to the scientific development of the author's concept of "mechanism of economic and legal regulation of water transport" - a system of legal means aimed at streamlining economic relations in water transport, which is implemented with the help of subjects of organizational and economic authority and economic and legal regulation of water transport. Attention is paid to the categories of "transport system" and "unified transport system" with their reasonable distinction. The features and compo- 


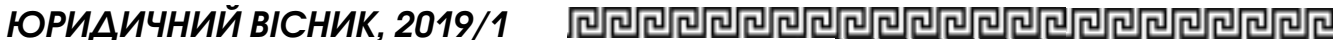

nents of the mechanism are detected, and also the place of the mechanism among the mechanisms available in a scientific turnover and in the transport system of Ukraine is defined.

\section{Література}

1. Прилущький Р.Б. Правові механізми у сфері господарювання. Юридична наука. 2013. № 5. C. 26-39.

2. Братусь С.Н. Право и хозяйственньий механизм. Правоведение. 1983. № 4. С. 29-37; Советское законодательство и хозяйственный механизм/ С.Н. Братусь, Л.В. Бричко, А.Б. Венгеров, В.В. Глазырин, Н.И. Клейн, М.Г. Масевич, А.Ф. Ноздрачев, И.Н. Петров, В.А. Рахми лович, А.И. Ставцева, И.Д. Тиновицкая. Москва : Юрид. лит., 1984. 272 с.; Мельник Л.Ю., Макаренко А.П. Зміст та складові господарського механізму у ринковій економіці. Інвестиції: практика та досвід. 2007. № 24. С. 10-12; Паламарчук В. Господарський механізм - підсистема державного регулювання економіки. Право України. 2001. № 10. С. 25-29 та ін.

3. Мамутов В.К. Экономико-правовой подход к исследованию проблем управления общественным производством. Экономико-правовые проблемы совершенствования хозяйственного механизма. Москва : Институт государства и права Академии наук СССР, 1984. C. 18 .

4. Хозяйственное право : учебник / под общ. ред. акад. В.К. Мамутова. Москва : Юринком Интер, 2002. 970 c.
5. Про транспорт : Закон України. Відомості Верховної Ради України. 1994. № 51. Cm. 446 .

6. Лопатина Н.Ф. Единая транспортная система (хозяйственно-правовые аспекты). Москва: Наука, 1988. 160 с.

7. Ващенко Н., Кублій А. Структурні особливості розвитку транспортної системи України. Підприємниитво, господарство і право. 2005. № 6. С. 148-150.

8. Дорофеєва, Х.М. Аналіз показників діяльності транспортної системи Украінни. Вісник соціально-економічних досліджень : збірник наукових праць / за ред.: M.I. Звєрякова (голов. ред.) та ін. Одеса: Одеський національний економічний універcumem, 2015. Bun. 1. № 56. C. 56-62.

9. Загальний курс транспорту: навчальний посібник / М.I. Міщенко, А.В. Хімченко, І.Ф. Вороніна, Ф.М. Судак. Донещьк : Hopd-npec, 2010. 323 c.

10. Матвеєва А.В. Національна транспортна безпека: правова природа та ознаки. Право та інновації. 2016. № 4. С. 9-15.

11. Савичев Г.П. Правовое регулирование перевозок народнохозяйственных грузов. Москва : Изд-во МГУ, 1986. 150 с.

12. Кондратьев В.М. Совершенствование правового регулирования транспортно-хозяйственной системь. транспортно-экономические связи и размещение производства : тез. докл. Всесоюз. конф. Алма-Ата, 1983. T. 2. C. 237.

13. Транспортне право України: навчальний посібник / Е.Ф. Демський, В.К. Гіжевський, С.Е. Демський, А.В. Мілашевич ; за заг. ред. В.К. Гіжевського, Е.Ф. Демського. Київ : Юрінком Iнтер, 2002. 416 с. 